\title{
Analisis Proses Kognitif Siswa Dalam Pemecahan Masalah Berdasarkan Taksonomi Bloom Revisi
}

\author{
Timotius Woda Napu \\ Fakultas Keguruan dan Ilmu Pendidikan, Universitas Sanata Dharma. Mrican Tromolpos 29 \\ Yogyakarta 55022, Indonesia., Telp: +6282339645602 \\ * Korespondensi Penulis. E-mail: mailto:timotiusnapu@ gmail.com
}

\begin{abstract}
Abstrak. Tujuan penelitian ini untuk mengetahui proses kognitif yang terjadi dalam pemecahan masalah siswa Kelas VIII A SMPK St. Paulus Karuni. Jenis penelitian ini adalah penelitian deskriptif kualitatif, dengan menganalisis hasil peserta didik berdasarkan Taksonomi Bloom Revisi. Subyek penelitian ini adalah siswa VIII A SMPK St. Paulus Karuni tahun ajatan 2018/2019 yang terdiri dari 11 siswa, yaitu sebuah kelas khusung yang menggunakan pendekatan metakognitif dan diskursif pada pembelajaran matematika. Pengumpulan data pada penelitian deskriptif kualitatif ini adalah berupa hasil tes dari siswa. Sebagai data penunjang dalam penelitian ini, siswa diberikan aturan khusus dalam melaksanakan tes. Yaitu siswa hanya boleh membuat cakaran di samping dari jawaban yang diberikan. Berdasarkan hasil dan pembahasan siswa kelas VIII A SMPK St. Paulus Karuni yang terdiri dari 11 siswa, terdapat empat jenis jawaban berbeda. Hasil analisis proses kognitif adalah 9 siswa dengan jenis jawaban pertama dan keempat mampu mancapai tingkatan C5 atau memenuhi lima indikator pertama. Satu siswa dengan jenis jawaban kedua mampu mancapai tingkatan C4 atau memenuhi 4 indikator pertama. Sedangkan satu siswa lainnya yang memiliki jenis jawaban ketiga, mampu mencapai tingkatan $\mathrm{C} 2$ atau hanya terpenuhi dua indikator pertama.
\end{abstract}

Kata kunci: Proses Kognitif; Pemecahan Masalah; Taksonomi Bloom Revisi.

Abstract. The purpose of this research was to determine the cognitive processes that occur in problem solving for Class VIII A students of SMPK St. Paulus Karuni. Type of this research is a qualitative descriptive research, by analyzing the results of students based on Bloom's Revised Taxonomy. The subjects of this research were students of VIII A SMPK St. Paulus Karuni in the 2018/2019 academic year consisting of 11 students, which is a special class that uses a metacognitive and discursive approach to mathematics learning. Collecting data in this qualitative descriptive research is in the form of test results from students. As supporting data in this research, students are given special rules in carrying out tests. Namely students may only make scratches in addition to the answers given. Based on the results and discussion of students of class VIII A SMPK St. Paulus Karuni consisting of 11 students, there are four different types of answers. The results of the cognitive process analysis are 9 students with the first and fourth types of answers able to reach the C5 level or meet the first five indicators. One student with the second type of answer is able to reach the C4 level or meet the first 4 indicators. Whereas one other student who has the third type of answer, is able to reach level C2 or only meet the first two indicators.

Keywords: Cognitive Process; Solution to problem; Bloom's Revised Taxonomy. 


\section{PENDAHULUAN}

Pendidikan matematika di Indonesia, secara umum belum pernah memberikan hasill yang menggembirakan baik untuk skala nasional mau pun internasional. Indonesia masih jauh tertinggal oleh negara-negara lain. Sebagai pendidik sangat berharap agar mata pelajaran matematika dapat lebih baik lagi. Namun kenyataannya yang sering kita temui di dunia pendidikan, hasil belajar siswa pada mata pelajaran matematika pada umumnya sangat rendah. Hal tersebut disebabkan oleh kurangnya keaktifan siswa di dalam proses belajar mengajar dan kurangnya keterampilan guru dalam memberikan materi pembelajaran. Kebanyakan guru juga memaksakan peserta didik untuk menghafal rumus tanpa memahami bagaimana prosesnya hingga terbentuk rumus itu. Akibatnya, peserta didik kurang kreatif dan kurang aktif dalam proses berpikir.

Salah satu upaya yang dilakukan untuk mengatasi masalah tersebut adalah STKIP Weetebula membangun proyek kerja sama dengan misereor Jerman untuk meningkatkan kualitas pendidikan di Indonesia khususnya di sumba. Tujuan dari proyek ini adalah untuk meningkatkan mutu pendidika dengan cara mendidik para siswa, mahasiswa dan guru memiliki kemampuan berpikir kritis dan bernalar. Untuk mencapai tujuan ini, teknik utama yang harus dilakukan adalah meningkatkan kualitas pengajaran yang bermutu artinya siswa dan guru harus belajar memberi alasan, memonitor setiap pernyataan, mereflesikan dan mengevalusi pemecahan masalah. Kegiatan ini disebut dengan metakognitif. Kerja sama ini dimulai sejak tahun 2012, hingga sekarang 2019. Namun, proyek ini baru dimulai pada tahun 2017 di SMPK St. Paulus.

Upaya ini dilakukan untuk meningkatkan pengalaman metakognitif peseta didik disertai dengan tindakan kognitif. Pengalaman metakognitif yang dimaksud adalah pengalaman yang membutuhkan pertimbangan secara sadar pengalaman intelektual yang menyertai setiap kegagalan atau keberhasilan dalam belajar. Menurut Livingstone (dalam Kamid 2013) pengalamanpengalaman metakognitif melibatkan strategi metakognitif atau pengaturan metakognitif. Strategi-strategi metakognitif merupakan proses-proses yang berurutan yang digunakan untuk mengontrol aktivitas-aktivitas kognitif dan memastikan bahwa tujuan kognitif telah dicapai. Berdasarkan uraian-uraian diata, peneliti ingin meneliti proses kognitif yang terjadi pada saat siswa memecahkan masalah matematika yang diberikan oleh guru. Sehingga peneliti memilih judul untuk penelitian ini adalah "Analisis Proses Kognitif Berdasarkan Taksonomi Bloom Revisi dalam Pemecahan Masalah Siswa Kelas VIII A SMPK St. Paulus Karuni”.

\section{METODE}

\section{a. Jenis Penelitian}

Jenis penelitian ini adalah penelitian deskriptif kualitatif. Menurut David Williams (dalam Moleong, 2009: 5) Penelitian kualitatif adalah pengumpulan data pada suatu latar alamiah, dengan menggunakan metode alamiah, dan dilakukan oleh orang atau peneliti yang tertarik secara alamiah. Yaitu dengan maksud menafsirkan fenomena yang terjadi dan dilakukan dengan cara melibatka berbagai metode yang ada, seperti wawancara, pengamatan dan pemanfaatan dokumen.

\section{b. Subjek Penelitian}

Subyek penelitian adalah siswa kelas VIII A SMPK St. Paulus Karuni. Subjek ini adalah kelas khusus yang menggunakan pendekatan metakognitif diskursif pada pembelajaran matematika, yang diselenggarakan oleh tim Lembaga Matematika Kognitif STKIP Weetebula dan bekerja sama dengan Misereor Jerman. Dimana peneliti sendiri adalah salah satu guru yang bekerja dalam tim ini.

\section{c. Waktu dan Tempat Penelitian}

Penelitian ini dilaksanakan pada tannggal 01 April 2019, di SMPK St. Paulus Karuni, Desa Karuni, Kec. Loura, Kab. Sumba Barat Daya, Nusa Tenggara Timur.

\section{d. Instrumen Penelitian}

Instrumen analisis proses kognitif siswa dalam penelitian ini berupa atruan tes dan soal tes yang dirancang untuk 
megetahui proses kognitif siswa dari materi persamaan yang terdiri dari satu soal.

\section{e. Tahapan Penelitian}

Penelitian terdiri dari beberapa tahapan yaitu studi pendahuluan di sekolah yang bersangkutan, pembuatan instrumen, pengumpulan data yang dilakukan dengan cara melakukan tes, dan tahap pengoreksian.

\section{f. Teknik Analisis Data}

Analisis data dalam penelitian ini menggunakan analisis data kualitatif. Data kualitatif adalah semua bahan, keterangan, dan fakta-fakta yang tidak dapat diukur dan dihitung secara matematis karena berwujud keterangan verbal. Data kualitatif yaitu hasil hasil pekerjaan siswa. Terdapat tiga teknik analisis data kualitatif yaitu:

\section{Reduksi Data}

Reduksi data adalah bentuk analisis yang menajamkan, menggolongkan, mengarahkan, membuang yang tidak perlu dan mengorganisasi data sedemikian rupa sehingga kesimpulan akhir dapat diambil.

2. Penyajian Data

Penyajian data adalah kegiatan ketika sekumpulan informasi disusun, sehingga memberi kemungkinan akan adanya penarikan kesimpulan. Bentuk penyajian data kualitatif berupa teks naratif, matriks, grafik, jaringan dan bagan.

3. Penarikan Kesimpulan

Penarikan kesimpulan adalah hasil analisis yang dapat digunakan untuk mengambil suatu tindakan.

\section{HASIL DAN PEMBAHASAN}

Penelitian ini dilakukan pada siswa kelas VIIA SMPK St. Paulus Karunu yang terdiri dari sebelas siswa untuk menganalisis kemampuan proses kognitif. Yang diteliti adalah siswa yang terlebih dahulu mengikuti pembelajaran matematika pada materi persamaan dengan pendekata metakognitif dan diskursif. Peneliti bertindak sebagai saalah satu tim guru yang dalam pembelajaran. Setelah selesai melaksanakan pembelajaran dengan pendekatan metakognitif dan diskursif, diberikat tes yang terdiri dari satu soal denagn waktu 15 menin. Sebagi penunjang data, peneliti juga memberikan aturan khusus dalam melaksanakan tes. Aturan-aturannya adalah bekerja sendiri, tidak boleh diskusi, duduk berjauhan, tidak bole menggunakan pensil (hanya boleh dengan pulpen), tidak boleh menggunakan tip ex, jika ingin koreksi cukup dengan melingkar jawaban yang salah dan menulis jawaban yang baru pada tempat yang mungkin bisa dan siswa hanya boleh mencakar pada lembar jawaban.

Indikator yang digunakan untuk mengukur proses kognisi siswa dalam penelitian ini adalah: 1) Mengingat (remembering). Mampu mengenali dan mengingat/ mengambil kembali pengetahuan/ informasi yang relevan yang tersimpan dalam ingatan/ memori, 2) Mema $\neg$ hami (understanding). Membangun makna dari pesan lisan, tertulis, dan grafis dengan cara menafsirkan, mencontohkan dan mengklasifikasi serta mengerti apa yang harus dilakukan selanjutnya. 3) Menerapkan (applying). Melaksanakan atau meng ᄀgunakan konsep melalui mengeksekusi, atau pelaksanaan untuk memecahkan masalah. 4) Menganalisis (analyzing). Mampu memisahkan konsep ke dalam beberapa komponen dan menghubungkan satu sama lain untuk memperoleh pemahaman atas konsep tersebut secara utuh. 5) Mengevaluasi (evaluating). Siswa mampu memeriksa/ mengecek kembali proses pemecahan masalah yang telah diperoleh siswa. 6) Mencipta (creating). Siswa mampu menciptakan konsep baru berdasarkan konsep-konsep yang telah ada.

Sehingga pada pembahasan ini peneliti tdak lagi membahas semua jawaban dari masing-masing siswa, melainkan dari tiga jenis jawaban yang berbeda.

Soal tes yang digunakan dalam penelitian ini adalah sebagai berikut:

Jumlah dari tiga bilangan asli yang berurut adalah 93. Tentukanlah ketiga bilngan tersebut!

Bilangan yang terkecil

Bilangan yang di tengah

Bilangan yang terbesar

\section{Analisis Proses Kognitif Siswa}

Berdasarkan hasil tes dari 11 siswa, peneliti mengkategorikan ke dalam 4 jenis 
jawaban yang berbeda. Untuk jenis jawaban yang pertama terdapat 5 siswa yang memiliki jawaban serupa, jenis jawaban kedua terdapat 1 siswa, jenis jawaban yang ketiga terdapat 1 siswa dan jenis jawaban ke empat terdapat 4 siswa yang memiliki jawaban serupa.

Analisis jenis jawaban siswa adalah sebagai berikut:

a. Jenis jawaban pertama, terdiri dari 5 siswa.

Jenis jawan siswa yang pertama ditunjukkan pada Gambar 1 berikut ini.

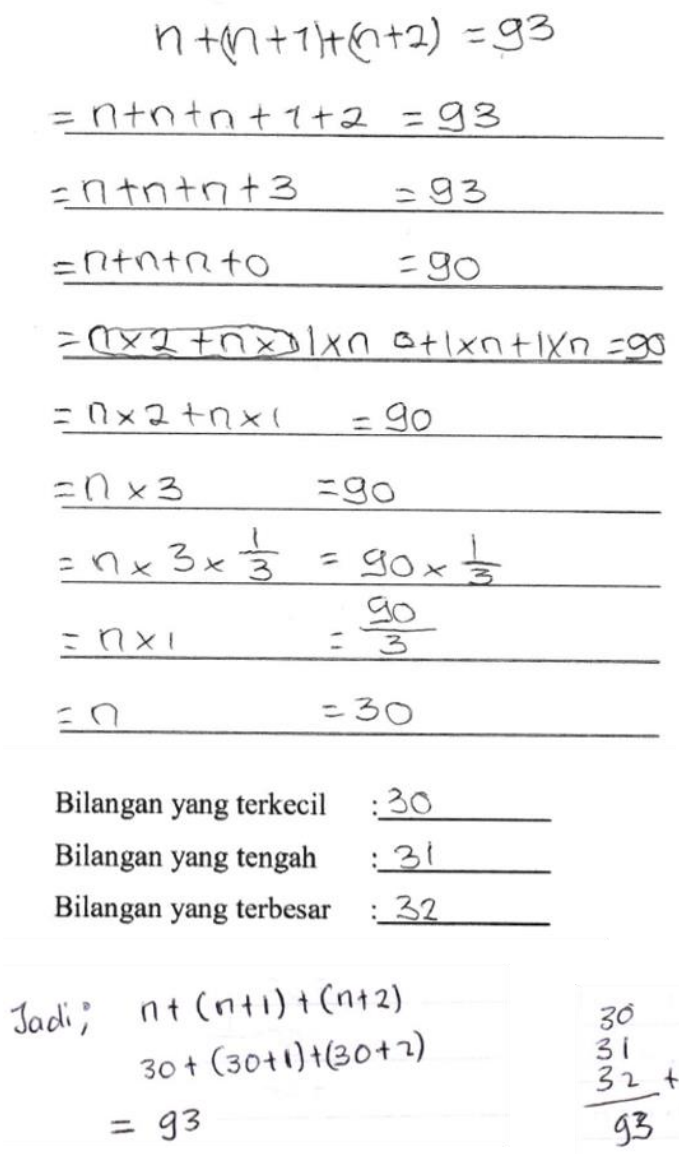

Gambar 1. Jenis jawaban pertama

\section{$\mathrm{C} 1$. Mengingat (remembering)}

Pada tahap ini, siswa menerjemahkan kalimat "Jumlah dari tiga bilangan asli yang berurut adalah 93" dalam bentuk persamaan $n+(n+1)+(n+2)=93$. Hal ini terlihat bahwa siswa mengingat bilangan asli serta cirinya, yaitu setiap dua bilangan bulat yang berurutan amemiliki selisih satu. Sehingga dapat disimpulkan bahwa siswa memenuhi indikator ini, yaitu mampu mengenali dan mengingat/ mengambil kembali pengetahuan/ informasi yang relevan yang tersimpan dalam ingatan/memori.

C2. Memahami (understanding)

Pada tahap ini siswa sudah memahami informasi dan perintah dari masalah yang diberikan. Hal ini terlihat pada jawaban siswa saat menjerjemakan informasi dalam bentuk persamaan $n+(n+1)+$ $(n+2)=93$. Siswa mampu memisalka 3 bilangan asli masing-masing dengan $\mathrm{n}$, $(n+1)$ dan $(n+2)$.Sehingga dapat disimpulkan bahwa siswa memenuhi indikator ini, yaitu mampu membangun makna dari pesan lisan, tertulis, dan grafis dengan cara menafsirkan, mencontohkan dan mengklasifikasi serta mengerti apa yang harus dilakukan selanjutnya.

C3. Menerapkan (applying)

Pada tahap ini siswa menerapkan konsepkonsep matematika yang sudah dipelajari sebelumnya, yaitu konsep persamaan, distributif, penjumlah, pengurangan, perkalian serta konsep-konsep lainnya untuk memperoleh solusi dari persamaan. Sehingga dapat disimpulkan bahwa siswa memenuhi indikator ini, yaitu mampu melaksanakan atau menggunakan konsep melalui mengeksekusi, atau pelaksanaan untuk memecahkan masalah.

C4. Menganalisis (analyzing)

Pada tahapan ini siswa memisahkan konsep-konsep dalam beberapa komponen untuk memudakannya dalam mencari solusi. Yaitu siswa mengelompokkan variabel dengan variabel dan konstanta dengan konstanta kemudian menghitung solusinya. Sehingga dapat disimpulkan bahwa siswa memenuhi indikator ini, yaitu mampu memisahkan konsep ke dalam beberapa komponen dan menghubungkan satu sama lain untuk memperoleh pemahaman atas konsep tersebut secara utuh.

C5. Mengevaluasi (evaluating)

Pada tahap ini siswa melakukan tahap evaluasi. Terlihat pada jawaban siswa terdapat jawaban yang dilingkar, juga pada cakara, siswa melakuka pegecekan kembali mengenai tiga bilanga asli yang sudah diperoleh. Maka dapat disimpulkan 
bawak siswa memenuhi indikator ini, yaitu mampu memeriksa/ mengecek kembali proses pemecahan masalah yang telah diperoleh siswa.

C6. Mencipta (creating)

Pada tahan ini siswa belum memenuhi indikator ini, yaitu siswa tidak mampu menciptakan konsep baru berdasarkan konsep-konsep yang telah ada.

Berdasarkan hasil diatas, siswa yang memiliki jeni jawaban pertama, mampu mancapai tingkatan $\mathrm{C} 5$, yaitu siswa dapat memenuhi 5 indikator pertama.

\section{b. Jenis jawaban kedua, terdiri dari 1 siswa}

Jenis jawan siswa yang kedua ditunjukkan pada Gambar 2 berikut .

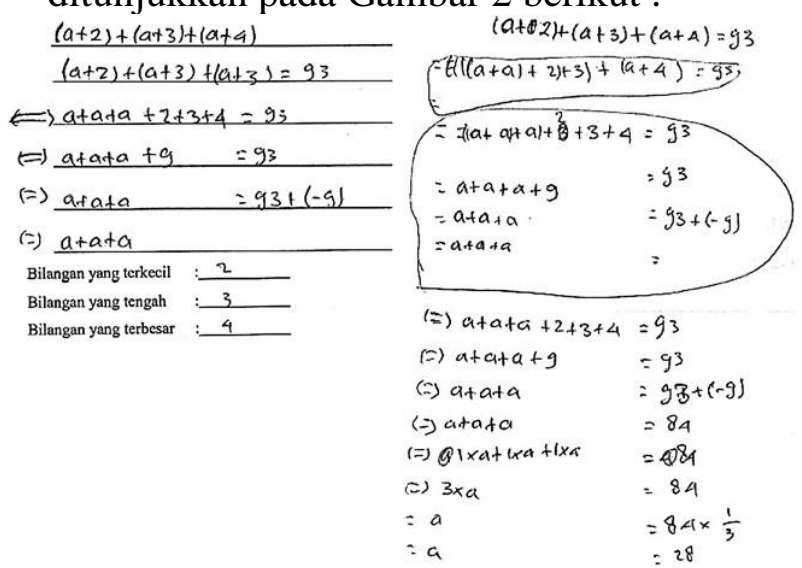

Gambar 2. Jenis jawaban kedua

\section{C1. Mengingat (remembering)}

Pada tahap ini, siswa menerjemahkan kalimat "tiga bilangan asli berurutan dalam bentuk $(a+2)+(a+3)+(a+$ 4). Hal ini terlihat bahwa siswa mengingat Siswa mengingat bilangan asli serta cirinya yaitu setiap dua bilangan bulat yang berurutan amemiliki selisih satu. Sehingga dapat disimpulkan bahwa siswa memenuhi indikator ini, yaitu mampu mengenali dan mengingat/ mengambil kembali pengetahuan/ informasi yang relevan yang tersimpan dalam ingatan/ memori.

C2. Memahami (understanding)

Pada tahap ini terlihat bahwa siswa sudah memahami informasi dari masalah yang diberikan, namun siswa tidak secara untuk memahami perintah dari soal. Hal ini terlihat pada jawaban siswa menjerjemakan informasi dalam bentuk persamaan $(a+2)+(a+3)+(a+$ $4)=93$, namun untuk menemuka ketiga bilangan belum belum mksimal. Berdasarkan uraian diatas, dapat disimpulkan bahwa siswa memenuhi indikator ini, yaitu mampu membangun makna dari pesan lisan, tertulis, dan grafis dengan cara menafsirkan, mencontohkan dan mengklasifikasi serta mengerti apa yang harus dilakukan selanjutnya.

C3. Menerapkan (applying)

Pada tahap ini siswa siswa menerapkan konsep-konsep yang sudah dipelajari sebelumnya, yaitu konsep persamaan, distributif, penjumlah, pengurangan, perkalian serta konsep-konsep lainnya untuk memperoleh solusi dari persamaan. Sehingga dapat disimpulkan bahwa siswa memenuhi indikator ini, yaitu mampu melaksanakan atau menggunakan konsep melalui mengeksekusi, atau pelaksanaan untuk memecahkan masalah.

C4. Menganalisis (analyzing)

Pada tahapan ini siswa memisahkan konsep-konsep dalam beberapa komponen untuk memudakannya dalam mencari solusi. Yaitu terlihat pada penyelesaian persamaan $(a+2)+(a+$ $3)+(a+4)=93, \quad$ siswa mengelompokkan variabel dengan variabel dan konstanta dengan konstanta, kemudian menghitungnya. Maka dari itu, dapat disimpulkan bahwa siswa memenuhi indikator ini, yaitu mampu memisahkan konsep ke dalam beberapa komponen dan menghubungkan satu sama lain untuk memperoleh pemahaman atas konsep tersebut secara utuh.

C5. Mengevaluasi (evaluating)

Pada tahap ini siswa melakukan tahap evaluasi namun tidak maksimal. Terlihat pada jawaban yang dilingkat. Siswa kurang yakin akan jawabannya dan terdapat kesalahan penggunaan tanda sama dengan sebanyak dua kali, sehingga siswa memberi tanda salah (melingkar jawaban) kemudian menuliskan jawaban yang benar. Namun untuk menuliskan 3 bilangan asli, siswa tidak melakukan evaluasi, siswa tidak mengecek kembali 
jawabannya. Maka dapat disimpulkan, untuk indikator ini, siswa belum mampu memeriksa/ mengecek kembali proses pemecahan masalah yang telah diperoleh siswa.

C6. Mencipta (creating)

Pada tahan ini siswa belum memenuhi indikator ini, yaitu siswa tidak mampu menciptakan konsep baru berdasarkan konsep-konsep yang telah ada.

Berdasarkan analisis diatas, siswa yang memiliki jeni jawaban kedua mampu mancapai tingkatan $\mathrm{C} 4$, yaitu siswa hanya dapat memenuhi 4 indikator pertama.

c. Jenis jawaban ketiga, terdiri dari 1 siswa Jenis jawan siswa yang ketiga ditunjukkan pada Gambar 3 berikut.

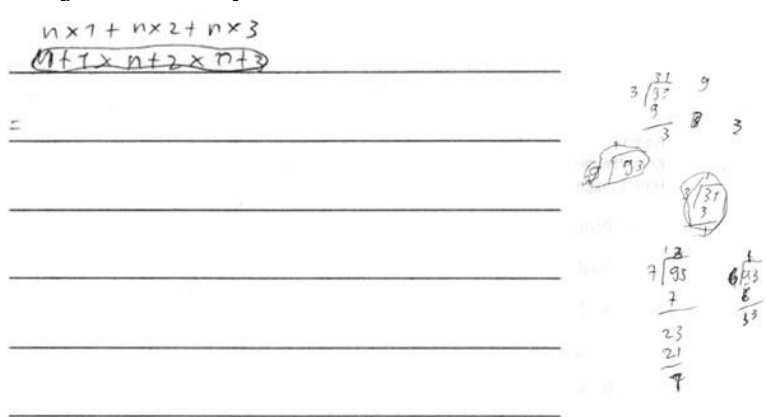

Bilangan yang terkecil

Bilangan yang tengah

Bilangan yang terbesar

Gambar 3. Jenis jawaban ketiga

\section{C1. Mengingat (remembering)}

Berdasarkan jawaban siswa, pada tahap ini siswa mengubah alimat "jumlah tiga bilangan asli berurutan adalah 93" dalam bentuk persaamaan $(n+1)+(n+2)+$ $(n+3)$. Siswa mampu mengenali, mengingat bilangan asli beserta cirinya, yaitu setiap dua bilangan asli berurutan amemiliki selisih satu sehingga siswa dapat memisalkan dengan $\quad(n+1)$, $(n+2)$ dan $(n+3)$. Maka dapat disimpulkan bahwa siswa mampu mengenali dan mengingat/ mengambil kembali pengetahuan/informasi yang relevan yang tersimpan dalam ingatan/ memori.

C2. Memahami (understanding)
Pada tahap ini siswa smengigat dan mengingat informasi yang terkai dengan masalah, yaitu bilangan asli dan cirinya. Terlihat ketika siswa menterjemahkan kalima "tiga bilangan asli berututan" dalam betuk matematika. Siswa meminsalkan masing-masing bilangan dengan $(n+1),(n+2)$ dan $(n+3)$. Siwa juga memahami perintah dari soal, namun tidak mengerti langkah apa yang harus dilakukan terlihat pada cakaran siswa ketika menghitung jumlah 3 bilangan asli (23, 24, dan 25) namun tidak menghasilkan 93. Maka dapat disimpulkan bahwaa siswa mampu indikator ini. Yaitu siswa dapat membangun makna dari pesan lisan, tertulis, dan grafis dengan cara menafsirkan, mencontohkan dan mengklasifikasi serta mengerti apa yang harus dilakukan selanjutnya.

C3. Menerapkan (applying)

Pada tahap ini, siswa tidak mampu menerapkan konsep-konsep yang sudah dipelajari sebelumnya. Sehingga siswa tersebut tidak memenuhi indikator ini, yaitu siswa belum melaksanakan atau menggunakan konsep melalui mengeksekusi atau pelaksanaan untuk memecahkan masalah.

C4. Menganalisis (analyzing)

Pada tahapan ini siswa tidak mampu menganalisis, memisahkan konsep dan menghubungkan dengan konsep lain. Sehingga disimpulkan siswa tidak memenuhi indikator ini.

C5. Mengevaluasi (evaluating)

Pada jawaban ini, siswa tidak mampu memahami, menerapkan serta menganalisis masalah yang diberikan, akibatnya siswa tidak dapat melakukan evaluasi.

C6. Mencipta (creating)

Pada tahan ini siswa belum memenuhi indikator ini, yaitu siswa tidak mampu menciptakan konsep baru berdasarkan konsep-konsep yang telah ada.

Berdasarkan hasil diatas, siswa yang memiliki jeni jawaban ketiga mampu 
mancapai tingkatan $\mathrm{C} 2$, yaitu siswa hanya mampu memenuhi dua undikator pertama.

d. Jenis jawaban ketiga, terdiri dari 1 siswa

Jenis jawan siswa yang keempat ditunjukkan pada Gambar 4 berikut.

$$
\begin{aligned}
& \frac{3 \times m+3=93}{(m+20+m+1(m+1)=93 \quad(m+(m+1)+(m+2)=93} \\
& 3 x m+3=93 \\
& \stackrel{T P^{+}}{\longrightarrow} \quad 3 \times m=96 \\
& \stackrel{T P^{N}}{\Rightarrow} m=30
\end{aligned}
$$

$$
\begin{array}{l:c}
\text { Bilangan yang terkecil } & \frac{0}{30} \\
\text { Bilangan yang tengah } & \frac{3^{1}}{32} \\
\text { Bilangan yang terbesar } & :
\end{array}
$$

Gambar 4. Jenis jawaban keempat

\section{C1. Mengingat (remembering)}

Pada tahap ini, siswa menerjemahkan kalimat "Jumlah dari tiga bilangan asli yang berurut adalah 93" dalam bentuk persamaan $m \times 3+3=93$. Hal ini terlihat bahwa siswa mengingat bilangan asli serta cirinya. Sehingga dapat disimpulkan bahwa siswa memenuhi indikator ini, yaitu mampu mengenali dan mengingat/ mengambil kembali pengetahuan/ informasi yang relevan yang tersimpan dalam ingatan/ memori.

C2. Memahami (understanding)

Pada tahap ini siswa sudah memahami informasi dan perintah dari masalah yang diberikan. Hal ini terlihat pada jawaban siswa saat menjerjemakan informasi dalam bentuk persamaan $m \times 3+3=$ 93. Maka dapat disimpulkan bahwa siswa memenuhi indikator ini, yaitu mampu membangun makna dari pesan lisan, tertulis, dan grafis dengan cara menafsirkan, mencontohkan dan mengklasifikasi serta mengerti apa yang harus dilakukan selanjutnya.

C3. Menerapkan (applying)

Pada tahap ini siswa menerapkan konsepkonsep matematika yang sudah dipelajari sebelumnya, yaitu konsep persamaan, distributif, penjumlah, pengurangan, perkalian serta konsep-konsep lainnya untuk memperoleh solusi dari persamaan. Maka dapat disimpulkan bahwa siswa memenuhi indikator ini, yaitu mampu melaksanakan atau menggunakan konsep melalui mengeksekusi, atau pelaksanaan untuk memecahkan masalah.

C4. Menganalisis (analyzing)

Pada tahapan ini siswa memisahkan konsep-konsep dalam beberapa komponen untuk memudakannya dalam mencari solusi. Siswa mengeliminasi bilangan seningga terdapat pada salah satu sisi tanda sama dengan dan variabel pada sisi yang lain. Maka dapat disimpulkan bahwa siswa memenuhi indikator ini, yaitu mampu memisahkan konsep ke dalam beberapa komponen dan menghubungkan satu sama lain untuk memperoleh pemahaman atas konsep tersebut secara utuh.

C5. Mengevaluasi (evaluating)

Pada tahap ini siswa melakukan tahap evaluasi. Terlihat pada jawaban siswa terdapat jawaban yang dilingkar jawaban yang salah dan menggantikan dngan jawaban yang benar. Maka dapat disimpulkan bawak siswa memenuhi indikator ini, yaitu mampu memeriksa/ mengecek kembali proses pemecahan masalah yang telah diperoleh siswa.

C6. Mencipta (creating)

Pada tahan ini siswa belum memenuhi indikator ini, yaitu siswa tidak mampu menciptakan konsep baru berdasarkan konsep-konsep yang telah ada.

Berdasarkan hasil diatas, siswa yang memiliki jeni jawaban pertama, mampu mancapai tingkatan $\mathrm{C} 5$, yaitu siswa dapat memenuhi 5 indikator pertam.

\section{KESIMPULAN}

Berdasarkan hasil dan pembahasan, siswa kelas VIII A SMPK St. Paulus Karuni terdiri dari 11 siswa sebagai subjek penelitian. Setelah dilakukan pengelompokan jawaban berdasarkan versi jawaban, terdapat 4 jenis jawaban yang berbeda. Hasil analisis proses kognitif dari 11 siswa adalah 9 siswa dengan jenis jawaban pertama dan jenis jawaban keempat mampu mancapai tingkatan C5 atau memenuhi lima indikator pertama. Satu siswa dengan jenis jawaban kedua mampu mancapai tingkatan $\mathrm{C} 4$ atau memenuhi 4 indikator pertama. Sedangkan satu siswa lainnya yang 
memiliki jenis jawaban ketiga, mampu mencapai tingkatan $\mathrm{C} 2$ atau hanya terpenuhi dua indikator pertama. Dari hasil ini, Peneliti menyimpulkan bahwa hasil nanalisis proses kognitif siswa dalam pemecahan masalah berdasarkan taksonomi Bloom revisi, terdapat $83 \%$ siswa mencapai tingkatan kongnitif C5, 9\% siswa mencapai tingkat kognitif C4 dan $9 \%$ siswa mencapai tingkat kognitif C2.

\section{DAFTAR PUSTAKA}

Dianivebi. 2012. 4 Lngkah Penyelesaian masalah.

http://dianiveby.blogspot.com/2012/0 6/4-langkah-penyelesaian-masalahmenurut.html. Diunduh pada tanggal 14 April 2019.

Gama, C. A., 2004, Integrating Metacognition Instruction in Interactive Learning Environment, D. Phil Dissertation, University of Sussex

Kamid. 2013. Metakognisi Siswa dalam Menyelesaikan Soal Matematika (Studi Kasus pada Siswa SMP Berdasarkan Gender). https://docplayer.info/47711828-

Metakognisi-siswa-dalammenyelesaikan-soal-matematikastudi-kasus-pada-siswa-smpberdasarkan-gender.html

Marpaung, Yansen. 2006. Karakteristik PMRI (Pendidikan Matematika Realistik Indonesia). Jurnal Pendidikan Matematika Mathedu, Surabaya.

Reet, Stephen K. 2011. Kognisi : Teori dan Aplikasi. Jakarta: Selemba Humanika

Sugiyono. 2010. Metode Penelitian Kuantitatif Kualitatif \& RND. Bandung: Alfabeta.

Suparni. 2000. Proses Berpikir Siswa SLTP dalam Menyelesaikan Soal-soal Operasi Hitung Pecahan Bentuk Aljabar. Surabaya: Pasca Sarjana Unesa.

Wicasari, Bella., dan Ernaningsih, Zeny. 2016. Analisis Kemampuan Berpikir Siswadalam Menyelesaikan Permasalahan Matematikayang Berorientasi pada Hots https://www.usd.ac.id/seminar/snrp2

016/wp-

content/uploads/2017/01/SNRP39.pd $\mathrm{f}$

Wikipedia Indonesia. Kognisi. https://id.wikipedia.org/wiki/Kognisi . Diakses pada tanggal 14 April 2019. Diakses pada tanggal 07 Mei 2019.

Zuhri, D. 2008. Proses Berpikir Siswa Kelas II SMP Negeri 16 Pekanbaru dalam Menyelesaikan Soal-soal Perbandingan Senilai dan Perbandingan Berbalik Nilai. Tesis. Surabaya: UNESA. 